\title{
Splenic Sequestration and Ineffective Erythropoiesis in Hemoglobin E- $\beta$-Thalassemia Disease
}

\author{
FREDERICK B. RUYMANN, ${ }^{(38)}$ LOU A. POPEJOY, AND ROBERT B. BROUILLARD \\ Departments of Pediatrics (F.B.R., L.A.P.) and Medicine (R.B.B.), Uniformed Services University of the Health \\ Sciences, School of Medicine, Walter Reed Army Medical Center, Washington, DC, USA
}

\begin{abstract}
Summary
A 13-year-old Thai female with hemoglobin E- $\beta$-thalassemia was evaluated for anemia and splenomegaly. Globin chain synthesis in a whole cell system revealed an absence of $\beta^{A}$ chains and excessive $\alpha$ chains. The $\alpha / \beta^{E}+\gamma$ ratio was 1.26 in bone marrow and 1.90 in peripheral blood. The average $\gamma / \beta^{E}$ ratio in bone marrow and peripheral blood was 0.36 compared to peripheral blood concentrations of $49 \%$ hemoglobin $E$ and $51 \%$ hemoglobin F. Homologous red cell ${ }^{51} \mathrm{Cr}$ half-life increased from 22.7 days to 32.8 days after splenectomy. Total circulating hemoglobin increased from 112.9 to $149.7 \mathrm{~g}$. Endogenous carbon monoxide productive $\left(\mathrm{V}_{\mathrm{co}}\right)$ as a measure of total heme catabolism decreased from 2.00 to $1.54 \mu \mathrm{mol} / \mathrm{hr} / \mathrm{kg}$. Ineffective erythropoiesis was manifested by an increased $\dot{V}_{\mathrm{Co}} / \mathrm{V}_{\text {heme-c }}$ ratio of 7.52 .
\end{abstract}

\section{Speculation}

Splenic sequestration may occur as a complicating factor in the anemia of hemoglobin $E$ - $\beta$-thalassemia. The mechanism of this disorder is probably related to excessive $\alpha$ chain production and hemoglobin $E$ instability.

Hemoglobin $\mathrm{E}$ is an abnormal hemoglobin particularly prevalent in Southeastern Asia and is best documented in Thailand where several comprehensive studies have shown its clinical importance $(15,27)$. An individual with either heterozygous or homozygous hemoglobin $\mathrm{E}$ usually experiences little more than a mild anemia $(5,7)$. However, in association with thalassemia, hemoglobin $\mathrm{E}$ may result in significant anemia and splenomegaly $(1,19,30)$. In Thailand alone it is estimated that 50,000 individuals have hemoglobin $\mathrm{E}-\beta$-thalassemia $(7,15,30)$.

The anemia in hemoglobin E- $\beta$-thalassemia is related to 1) ineffective erythropoiesis with unbalanced globin chain synthesis characteristic of thalassemia (32) and spontaneous hemoglobin E oxidation (13), and 2) subsequent sequestration of many of the damaged red cells that escaped from the marrow. This clinical hypersplenism has been documented in Thailand and splenectomies have been performed for this condition over the past 20 years with varying results $(30)$. Our patient afforded the opportunity to investigate for the first time the anemia of hemoglobin E- $\beta$ thalassemia using endogenous carbon monoxide production $\left(\dot{\mathrm{V}}_{\mathrm{CO}}\right)$ in correlation with autologous and homologous ${ }^{51} \mathrm{Cr}$-labeled red cell survival studies.

\section{MATERIALS AND METHODS}

Routine hematologic studies were performed by standard methods (6). The distribution of hemoglobin $F$ in red cells was determined by the acid elution method of Betke and Kleihauer (3). The alkali-resistant hemoglobin was measured according to the method of Betke et al. (4). Carboxymethyl cellulose chromatog- raphy (34) was performed on hemolysates of washed red cells obtained form the proposita before splenectomy (17). Horizontal starch gel electrophoresis (35) in Tris-EDTA-boric acid buffer, pH 9.0 , was performed according to a described procedure (12). Globin chain synthesis was determined in a whole-cell system (35) utilizing peripheral blood and bone marrow (24).

Determination of red cell survival was performed by labeling autologous and homologous red cells with ${ }^{51} \mathrm{Cr}$ according to the ICSH Panel on Diagnostic Application of Radioisotopes in Hematology (18). Informed consent was obtained from the parents for all procedures. The mean red cell lifespan was calculated for the autologous ${ }^{51} \mathrm{Cr}$-labeled red cells assuming an elution rate of $1.29 \% /$ day as calculated for $\beta^{\mathrm{A}}$ chains by Cline and Berlin (9).

The hemoglobin catabolism was calculated as equal to the total circulating hemoglobin divided by the mean, autologous red cell survival. Total circulating hemoglobin was obtained from the product of peripheral hemoglobin and ${ }^{51} \mathrm{Cr}$ blood volume. The whole body to peripheral venous hematocrit was assumed to be 1.00 in the presplenectomy calculation to compensate for the hypersplenic state (22).

The catabolism of circulating red cell hemoglobin heme ( $\left.\dot{\mathrm{V}}_{\text {heme-c }}\right)$ was calculated in micromoles per hr per $\mathrm{kg}$ using the formula of White et al. (33).

$\dot{\mathrm{V}}_{\text {heme-c }}(\mu \mathrm{mol} / \mathrm{hr} / \mathrm{kg}$

$$
\begin{aligned}
&=\frac{\mathrm{gHb} \text { catabolized } / \text { day }}{0.017 \mathrm{~g} / \mu \mathrm{mol}} \times \frac{1 \text { day }}{24 \mathrm{hr}} \\
& \times \frac{1}{\text { patient's weight }(\mathrm{kg})}
\end{aligned}
$$

Endogenous carbon monoxide production $\left(\dot{\mathrm{V}}_{\mathrm{CO}}\right)$ as a measure of total heme catabolism was determined using a rebreathing system (11). The $\mathrm{V}_{\mathrm{CO}}$ in micromoles per hr per $\mathrm{kg}$ was calculated according to the following equation $(11,21)$.

$\dot{\mathrm{V}}_{\mathrm{co}}(\mu \mathrm{mol} / \mathrm{hr} / \mathrm{kg})$

$$
=\frac{\Delta \mathrm{COHb} \%}{44.6 \mathrm{ml} / \mu \mathrm{mol}} \times \frac{\mathrm{CO}_{\mathrm{D}}}{\Delta \mathrm{COHb} \% \mathrm{D}}
$$

$$
\times \frac{1}{\text { patients wt }(\mathrm{kg})}
$$

Where $\Delta \mathrm{COHb} \%$ is the average hourly increase in the percentage of saturation of hemoglobin with $\mathrm{CO} ; \mathrm{CO}_{\mathrm{D}} / \Delta \mathrm{COHb} \%_{\mathrm{D}}$ is the dilution of added $\mathrm{CO}$ in the body and is determined by adding $20.2 \mathrm{ml}$ (STPD) of $99.5 \% \mathrm{CO}$ to the circuit $\left(\mathrm{CO}_{\mathrm{D}}\right)$ and measuring the resultant increase in the blood $\mathrm{COHb}$ percent $\left(\Delta \mathrm{COHb} \%_{\mathrm{D}}\right)$.

The ratio of $\dot{V}_{\mathrm{CO}} / \dot{\mathrm{V}}_{\text {heme-c }}$ was calculated as a measure of the ineffective erythropoiesis (33).

\section{RESULTS}

CLINICAL STUDIES

The proposita, a 13-year-old Thai female, presented with complaints of pallor, icterus, and easy fatigability since 2 years of age. 
A large spleen had been found by referring physicians. She had no history of malaria, hepatitis, or prior transfusions. The family pedigree is shown in Figure 1. The genetic father, also of Thai extraction, was common to all siblings but unavailable for study.

Physical examination revealed pallor, mild conjunctival icterus, and a grade II/IV apical systolic murmur. The liver was palpable $2 \mathrm{~cm}$ and the spleen $3 \mathrm{~cm}$ below the costal margin. The patient exhibited early pubertal changes. Roentgenographic studies of the skull, spine, and ribs revealed widening of the medullary space and cortical thinning.

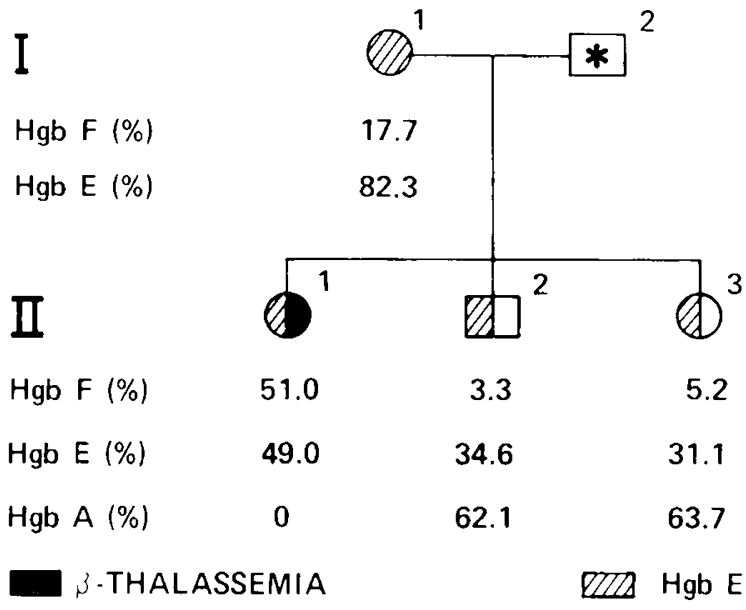

Fig. 1. Pedigree of proposita (II-1) with hemoglobin E- $\beta$-thalassemia. The genetic father was unavailable for study.
Peripheral blood studies revealed hematocrit $21 \%$, hemoglobin $7.0 \mathrm{~g} / 100 \mathrm{ml}, 13$ nucleated $\mathrm{RBCs} / 100 \mathrm{WBCs}$, and an uncorrected reticulocyte count of $5.3 \%$ (Table 1 ). On peripheral smear the red cells exhibited marked anisocytosis and poikilocytosis with many target cells, spherocytes, and fragmented forms. A bone marrow aspirate showed hypercellularity with erythroid hyperplasia (M/E $=0.5$ ). Iron stains were normal with a serum iron of $123 \mu \mathrm{g} / 100$ $\mathrm{ml}$ and TIBC of $248 \mu \mathrm{g} / 100 \mathrm{ml}$. Glucose-6-phosphate dehydrogenase activity was normal. The Coombs direct antiglobulin test was negative. Osmotic fragility had a tail with a double population of both osmotically sensitive and resistant cells.

Twenty-four hours before surgery the patient received $300 \mathrm{ml}$ packed red cells. At surgery a $17.5 \times 8.5 \times 3.0 \mathrm{~cm}$ spleen weighing $350 \mathrm{~g}$ was removed. Microscopic examination revealed littoral cell hyperplasia. There was no evidence of gallstone formation or gross hepatic disease at surgery. After an uneventful postoperative course the patient's activity tolerance increased in concert with rising hemoglobin values. A Heinz body preparation, negative before splenectomy, because positive after splenectomy.

The mother (I-1) was of pure Thai extraction and had enjoyed good health. Besides mild anemia, peripheral blood smears showed moderate targeting. The siblings (II-2 and II-3) of the proposita had no history of anemia, pallor, or icterus. Both their peripheral blood smears showed slight microcytosis and mild targeting.

\section{HEMOGLOBIN STUDIES}

Hemoglobin electrophoresis on cellulose acetate at $\mathrm{pH} 8.6$ revealed only two bands in the position of hemoglobins $E$ and $F$; no band was present in the area of hemoglobin $\mathrm{A}$. The $\mathrm{E}$ component was confirmed by starch gel electrophoresis and carboxymethyl-

Table 1. Hematologic data on proposita and family members

\begin{tabular}{|c|c|c|c|c|c|c|c|c|c|c|c|}
\hline Subject & Age (yr) & Diagnosis status & $\begin{array}{l}\mathrm{Hb}(\mathrm{g} / \\
100 \mathrm{ml})\end{array}$ & Het $(\%)$ & $\begin{array}{c}\text { RBC } \\
\left(\times 10^{6} / \mu \mathrm{l}\right) \\
\end{array}$ & $\begin{array}{c}\mathrm{MCH} \\
(\mathrm{pg})\end{array}$ & $\begin{array}{c}\mathrm{MCV} \\
(\mathrm{c} \mu)\end{array}$ & $\begin{array}{c}\mathrm{MCHC} \\
(\%)\end{array}$ & $\begin{array}{c}\text { Retic. } \\
(\%)\end{array}$ & $\begin{array}{c}\text { NRBC } \\
\text { (no./100 } \\
\text { WBC) }\end{array}$ & $\begin{array}{l}\text { Platelets } \\
\left(\times 10^{3}\right)\end{array}$ \\
\hline $\mathrm{I}-1$ & 36 & Hemoglobin $\mathrm{E}$ & 10.8 & 33.3 & 4.85 & 22.4 & 67 & 33 & 0.7 & 0 & 325 \\
\hline \multirow{3}{*}{ II- $1^{1}$} & 14 & Hemoglobin E- $\beta$-thal. & & & & & & & & & \\
\hline & & Presplenectomy & 7.0 & 21 & 3.38 & 21.0 & 63 & 32.7 & 5.3 & 13 & 260 \\
\hline & & Postsplenectomy & 9.1 & 29 & 4.17 & 22.3 & 66 & 32.8 & 5.9 & 79 & 1150 \\
\hline $\mathrm{II}-2$ & 12 & Hemoglobin $E$ trait & 12.9 & 39 & 5.62 & 23.8 & 70 & 33.8 & 1.8 & 0 & 305 \\
\hline II-3 & 8 & Hemoglobin $\mathrm{E}$ trait & 11.4 & 35 & 5.05 & 22.7 & 68 & 33.2 & 0.7 & 0 & 430 \\
\hline
\end{tabular}

${ }^{1}$ Proposita.

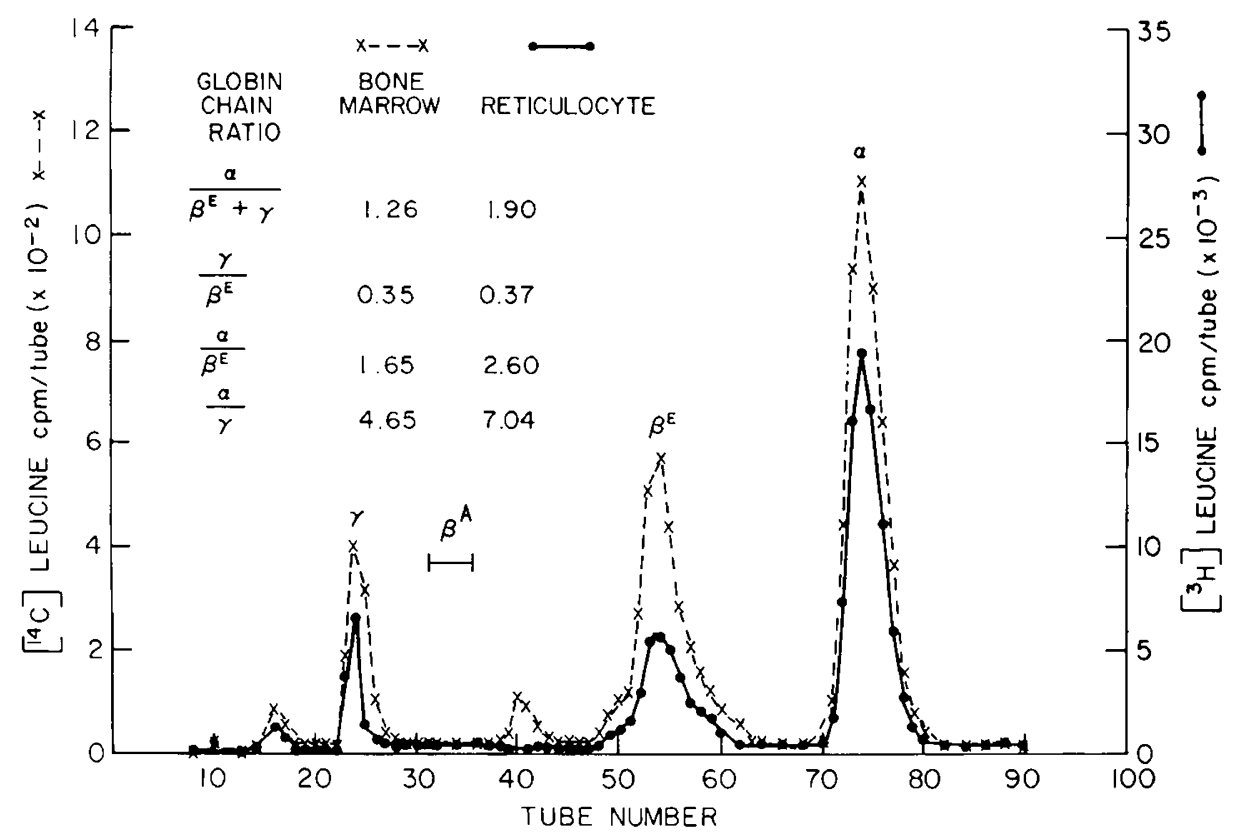

r. A n...-hanl hinad and hone marrow olnhin shain sunthesis in proposita with hemoglobin E- $\beta$-thalassemia. 
cellulose chromatography. Hemoglobin $\mathrm{F}$ was estimated at $51 \%$ by alkali denaturation; an acid elution hemoglobin $F$ exhibited a heterogenous distribution within the red cells. The measurement of globin chain synthesis in vitro showed an absolute absence of $\beta^{A}$ chain synthesis. Globin chain synthesis ratios in a whole cell system for bone marrow and peripheral blood are shown in Figure 2.

Cellulose acetate electrophoresis on blood from the mother showed major hemoglobin bands in the positions of hemoglobins $E$ and $F$, suggesting the diagnosis of homozygous hemoglobin $E$. Electrophoresis in the younger siblings showed major bands in the $A$ and $E$ position with mild elevation of hemoglobin $F$. These findings were consistent with hemoglobin $\mathrm{E}$ trait in both siblings.

\section{${ }^{51}$ CR RED CELL STUDIES}

The $t_{1 / 2}$ for both autologous and homologous ${ }^{51} \mathrm{Cr}$-labeled red cells are presented in Table 2. Technical problems prevented interpretation of autologous ${ }^{51} \mathrm{Cr} \mathrm{t}_{12}$ after splenectomy and the patient could not be restudied. The spleen/liver ratio was consistently above 2.0 for both autologous and homologous red cells. Mean red cell survival time as calculated from the autologous ${ }^{51} \mathrm{Cr}$ $t_{12}$ is presented in Table 3 . Total circulating hemoglobin showed an increase after splenectomy.

\section{ENDOGENOUS CARBON MONOXIDE PRODUCTION}

The $\dot{\mathrm{V}}_{\mathrm{CO}}$ presplenectomy was $2.00 \mu \mathrm{mol} / \mathrm{hr}$ and 2 months postsplenectomy was $1.54 \mu \mathrm{mol} / \mathrm{hr} / \mathrm{kg}$. Normal values previously reported by Bensinger et al. (2) in this laboratory are $\mathrm{V}_{\mathrm{CO}}=0.34$ $\pm 0.05 \mu \mathrm{mol} / \mathrm{hr} / \mathrm{kg}$ (mean $\pm \mathrm{SD}$ ). The $\mathrm{V}_{\mathrm{CO}} / \mathrm{V}_{\text {heme-c }}$ ratio was increased above the normal $\dot{\mathrm{V}}_{\mathrm{CO}} / \dot{\mathrm{V}}_{\text {heme-c }}$ ratio reported by White et al. (33) (Table 3).

\section{DISCUSSION}

In a review from Thailand, 143 splenectomies were performed in 408 patients with hemoglobin E- $\beta$-thalassemia; significant postoperative hematocrit elevation appeared limited to those patients with clinical hypersplenism (30). Wasi and Na-Nakorn (31) estimate that clinical hypersplenism occurs in about $10 \%$ of all cases with hemoglobin E- $\beta$-thalassemia in Thailand. Detailed decriptions, however, of hypersplenism with hemoglobin $E-\beta$ thalassemia are limited to two reports $(1,19)$.

The proposita survived into adolescence without a blood transfusion, which illustrates the adaptability of individuals with hemoglobin $E$ - $\beta$-thalassemia to a severe, chronic anemia. The pat-

Table 2. Erythrocyte ${ }^{51} \mathrm{Cr}$ studies on patient with hemoglobin $E$ - $\beta$-thalassemia

\begin{tabular}{lccc}
\hline & \multirow{2}{*}{$\begin{array}{c}\text { Red cell sequestration } \\
\text { by scan (spleen/ } \\
\text { liver ratio) }\end{array}$} & \multicolumn{2}{c}{ Half-Life (day) } \\
\cline { 3 - 4 } Erythrocyte source & $\begin{array}{c}\text { Presplenec- } \\
\text { tomy }\end{array}$ & $\begin{array}{c}\text { Postsplenec- } \\
\text { tomy }\end{array}$ \\
\hline Autologous & 2.8 & 14.6 & $\mathrm{NA}$ \\
Homologous & 2.1 & 22.7 & 32.8 \\
& $($ Normal $<2)$ & & $(\text { Normal }=30 \pm 4)^{1}$ \\
\hline
\end{tabular}

${ }^{1}$ Mean \pm SD tern on carboxymethylcellulose chromatography with complete absence of $\beta^{\mathrm{A}}$ chain synthesis strongly implies the diagnosis of hemoglobin $\mathrm{E}-\beta^{\circ}$-thalassemia. Only hemoglobin $\mathrm{E}$ behaves on carboxymethyl cellulose chromatography like hemoglobin $\mathrm{A}_{2}$; according to Huisman and Wrightstone (17), even hemoglobin ESaskatoon is separated by this technique. Hereditary persistence of fetal hemoglobin (HPFH) in combination with hemoglobin E has been reported in three cases (29). A heterogeneous distribution of hemoglobin $\mathrm{F}$ on acid elution staining excluded $\mathrm{HPFH}$ in our patient. The single report of a Thai family with hemoglobin E$\beta^{\delta}$-thalassemia (F-thalassemia) is of relevance (21). Strict exclusion of this diagnosis in our patient was impossible due to the nonavailability of the genetic father's hemoglobin $A_{2}$ and $F$ levels. The great rarity of $\beta^{\delta}$-thalassemia in Thailand made any diagnosis other than hemoglobin E- $\beta^{\circ}$-thalassemia highly improbable.

Unbalanced $\alpha$ chain synthesis in $\beta$-thalassemia has been shown to result in $\alpha$ chain denaturation and inclusion body formation (8, 14). Nathan and Gunn (23) have demonstrated alterations in membrane permeability as a consequence of unbalanced $\alpha$ chain synthesis in thalassemia. Whole cell lysates from Thai patients with hemoglobin E- $\beta$-thalassemia have been shown to have an absence of $\beta^{\mathrm{A}}$ chains with a marked increase in $\alpha / \beta^{\mathrm{E}}$ ratio (32). An $\alpha / \beta^{\mathrm{E}}$ synthesis ratio of 1.33 has been reported by Feldman and Reider (13) in hemoglobin E- $\beta^{\circ}$-thalassemia using washed, whole cell hemolysates. The whole cell synthesis studies in the proposita yielded bone marrow and peripheral blood $\alpha / \beta^{\mathrm{E}}$ ratios of 1.65 and 2.60 , respectively. The increased $\alpha / \gamma$ ratios observed in the proposita, 4.65 in bone marrow and 7.04 in peripheral blood, were consistent with the peripheral intact, red cell $\alpha / \gamma$ ratio of 5.55 observed by Feldman and Reider (13) in hemoglobin E$\beta$-thalassemia. Excessive $\alpha$ chain synthesis is again underlined by the combination $\alpha / \beta^{\mathrm{E}}+\gamma$ ratio, which consistently exceeded 1 in the bone marrow and peripheral blood of the proposita.

Structural analysis by Perutz and Lehmann (26) has predicted an instability of hemoglobin E. Recently, oxidative instability in hemoglobin $E$ has been confirmed by Frischer and Bowman (16). These authors have postulated an interference by the mutation with dimeric contact between $\alpha$ and $\beta$ chains $\left(\alpha_{1} \beta_{1}\right)$. In vitro synthesis of a globin chain in excess of corresponding peripheral hemoglobin values has been observed in several unstable hemo. globins (13). Although the peripheral blood concentrations of hemoglobin $\mathrm{E}$ and $\mathrm{F}$ are equal in the proposita, the synthesis of $\beta^{\mathrm{E}}$ in both bone marrow and peripheral blood is almost 3 times that of $\gamma$ chain synthesis. These results are consistent with the observations of Feldman and Reider (13) in hemoglobin E- $\beta$ thalassemia and imply a preferential destruction of hemoglobin E.

The shortened homologous ${ }^{51} \mathrm{Cr}$ labeled red cell half-life of 22.7 days and subsequent increase to a normal 32.8 days was consistent with splenic sequestration. Spleen to liver ratios in excess of 2.0 were also confirmatory. Erythrocytic phagocytosis has been observed by Bhamaprapravati et al. (5) in the splenic sinusoidal lining macrophages in an autopsy series of 20 patients with hemoglobin E- $\beta$-thalassemia. Increased trapping of erythrocytes in the splenic cords was observed in 8 out 13 cases by the same authors.

The mean autologous ${ }^{51} \mathrm{Cr}$-labeled red cell half-life calculated by Vigi et al. (28) with $\beta$-thalassemia major was 11.5 days. A

Table 3. Hemoglobin catabolism and $\mathrm{CO}$ production data

\begin{tabular}{lccccccc}
\hline \multicolumn{1}{c}{ Status } & $\begin{array}{c}\text { Body wt } \\
(\mathrm{kg})\end{array}$ & $\begin{array}{c}\text { Mean RBC } \\
\text { survival time } \\
\text { (days) }\end{array}$ & $\begin{array}{c}\text { Total circulating } \dot{\mathrm{V}}_{\text {heme-c }}(\mathrm{mol} / \mathrm{hr} / \\
\mathrm{Hb}(\mathrm{g})\end{array}$ & $\begin{array}{c}\text { COHb\% } \\
\text { (\%) saturation) }\end{array}$ & $\begin{array}{c}\dot{\mathrm{V}}_{\mathrm{o}}(\mathrm{mol} \\
/ \mathrm{hr} / \mathrm{kg})\end{array}$ & $\dot{\mathrm{V}}_{\mathrm{co}} / \dot{\mathrm{V}}_{\text {heme-c }}$ \\
\hline Presplenectomy & 35.9 & 29.0 & 112.9 & 0.266 & 0.34 & 2.00 & 7.52 \\
Postsplenectomy & 35.9 & 21.4 & 149.7 & 0.478 & 0.31 & 1.54 & 3.22 \\
Normal values (mean $\pm \mathrm{SD})$ & & & & & & $0.34 \pm 0.05^{2}$ & $1.27 \pm 0.26^{3}$ \\
\hline
\end{tabular}

${ }^{1}$ Corrected for elution of ${ }^{51} \mathrm{Cr}$.

${ }^{2}$ Bensinger et al. (2).

${ }^{3}$ White et al. (33). 
negative correlation between the excess $\alpha$ chain synthesis and the red cell survival was demonstrated. Interpretation of the 14.6-day erythrocyte ${ }^{51} \mathrm{Cr}$ half-life in the proposita with hemoglobin $\mathrm{E}-\beta$ thalassemia was complicated by a lack of elution data on hemoglobin E. Pearson (25) has shown that the ${ }^{51} \mathrm{Cr}$ elution from red cells containing hemoglobin $\mathrm{F}$ is comparable to that in red cells containing hemoglobin A. A comparison of the elution rate as measured by simultaenous $\mathrm{DF}^{32} \mathrm{P}$ and ${ }^{51} \mathrm{Cr}$ was not performed (10).

An index of ineffective erythropoesis is obtained by dividing the endogenous carbon monoxide production $\left(\dot{V}_{C O}\right)$, by the circulating red cell hemoglobin heme turnover $\left(\dot{\mathrm{V}}_{\text {heme-c }}\right)$. White et al. (33), in three of four patients with refractory anemia, demonstrated an increased $\dot{\mathrm{V}}_{\mathrm{CO}} / \dot{\mathrm{V}}_{\text {heme-c }}$ ratio compared to the normal $\dot{\mathrm{V}}_{\mathrm{CO}^{-}}$ $\dot{V}_{\text {heme-c }}$ ratio of $1.27 \pm 0.26$ (mean $\pm S D$ ). Recent confirmation of ineffective erythropoiesis using these methods has been obtained by Lundh et al. (20), who have recalculated the $\dot{\mathrm{V}}_{\mathrm{CO}^{-}} \dot{\mathrm{V}}_{\text {heme-c }}$ ratio in Coburn's material using total body hemoglobin obtained by ${ }^{51} \mathrm{Cr}$ rather than $\mathrm{CO}$ dilution. The resultant ratio of 1.44 is only slightly greater than Coburn's published $\dot{\mathrm{V}}_{\mathrm{co}} / \dot{\mathrm{V}}_{\text {heme-c }}$ ratio of 1.27 (11). Both methods confirm that total heme catabolism exceeds the catabolism of circulating red cell heme by $30-45 \%$. In hemoglobin $\mathrm{E}-\beta$-thalassemia a profound increase in total body heme catabolism relative to $\dot{V}_{\text {heme-c }}$ exists as manifested by the extremely high $\dot{\mathrm{V}}_{\mathrm{CO}} / \dot{\mathrm{V}}_{\text {heme-c }}$ ratio of 7.52 in the proposita. This value approaches the $\dot{\mathrm{V}}_{\mathrm{CO}} / \dot{\mathrm{V}}_{\text {heme-c }}$ ratio of 9.2 observed by White et al. (33) in patient A.V. with porphyria cutanea tarda. In patient M.L., with an intermediate type of thalassemia and hypersplenism, White et al. (33) reported a decrease in $\dot{V}_{\mathrm{CO}} / \dot{\mathrm{V}}_{\text {heme-c }}$ from 4.1 to 3.1 postsplenectomy; $\dot{V}_{\text {Co }}$ fell from 94.2 to $64.7 \mu \mathrm{mol} / \mathrm{hr}$. Similarly, in the proposita with hemoglobin E- $\beta$-thalassemia, a drop in $\dot{V}_{C O}$ from 2.00 to $1.54 \mu \mathrm{mol} / \mathrm{hr} / \mathrm{kg}$ was observed after splenectomy.

\section{CONCLUSION}

The recent influx of children from Southeast Asia has increased the likelihood of physicians in the Western hemisphere encountering patients with hemoglobin E- $\beta$-thalassemia. To measure the significance of splenic sequestration in a Thai child with hemoglobin $\mathrm{E}-\beta$-thalassemia ${ }^{51} \mathrm{Cr}$-labeled homologous red cell survivals were performed. The presplenectomy half-life was 22.7 days; the postsplenectomy value was 32.8 days. Studies of globin chain synthesis on peripehral blood and bone marrow documented increased $\alpha$ chain synthesis relative to combined $\beta^{\mathrm{E}}$ and $\gamma$. Carbon monoxide production, $\dot{\mathrm{V}}_{\mathrm{CO}}$, was $2.00 \mathrm{~mol} / \mathrm{hr} / \mathrm{kg}$, a value 5 times in excess of normal values. Markedly elevated $\mathrm{V}_{\mathrm{CO}} / \dot{\mathrm{V}}_{\text {heme-c }}$ ratios were present and indicative of ineffective erythropoiesis. Hemoglobin $\mathrm{E}-\beta$-thalassemia represents a multifactorial hemolytic anemia with hemoglobin $\mathrm{E}$ instability and excessive $\alpha$ chain production contributing to ineffective erythropoiesis. In some patients a component of splenic sequestration may contribute to the anemia and respond to splenectomy.

\section{REFERENCES AND NOTES}

1. Askoy, M., Cetingil, A. I., Kocabalkan, N., Sestakof, D., Aladag, T., Secer, F., and Bostance, N.: Thalassemia-hemoglobin E disease in Turkey with hypersplenism in one case. Amer. J. Med., 34: 851 (1963).

2. Bensinger, T. A., Maisels, M. J., Carlson, D. E., and Conrad, M. E.: Effect of low caloric diet on endogenous carbon monoxide production: Normal adults and Gilbert's syndrome. Proc. Soc. Exp. Biol. Med., 144: 417 (1973).

3. Betke, K., and Kleihauer, E.: Fetaler und bleibender blutfarbstuff in erythrozyten und erythroblasten von menschlichen feten und Neugeboren. Blut, 4: 241 (1958).

4. Betke, K., Marti, H. R., and Schlicht, I.: Estimation of small percentages of fetal hemoglobin. Nature (London) 184: 1877 (1959).

5. Bhamaprapravati, N., Na-Nakorn, S., Wasi, P., and Tuchinda, S.: Pathology of $\beta$-thalassemia hemoglobin E disease. Amer. J. Clin. Pathol, 47: 745 (1967).
6. Cartwright, G. E.: Diagnostic Laboratory Hematology, 4th Ed. (Grune \& Stratton, New York, 1968).

7. Chernoff, A. I., Minnich, V., Na-Nakorn, S., Tuchinda, S., Kashemsant, C. and Chernoff, R. R.: Studies of hemoglobin E. I. The clinical, hematologic and genetic characteristics of the hemoglobin E syndromes. J. Lab. Clin. Med., 47 455 (1956).

8. Clegg. J. B., Weatherall, D. J., Na-Nakorn, S., and Wasi, P.: Hemoglobin synthesis in $\beta$-thalassemia. Nature, 220: 664 (1968).

9. Cline, M. J., and Berlin, N. I.: The red cell chronium elution rate in patients with some hematologic diseases. Blood, 21: 63 (1963).

10. Cline, M. J., and Berlin, N. I.: An evaluation of DFP ${ }^{32}$ and $\mathrm{Cr}^{51}$ as methods of measuring red cell life span in man. Blood, 22: 459 (1963)

11. Coburn, R. F., Williams, W. J., and Kahn, S.B.: Endogenous carbon monoxide production in patients with hemolytic anemia. J. Clin. Invest., 45: 460 (1966)

12. Efremov, G. D., Huisman, T. H. J., Smith, L. L., Wilson, J. B., Kitchens, J. L. Wrightstone, R. N., and Adams, H. R.: Hemoglobin Richmond, a human hemoglobin which forms asymmetric hydrids with other hemoglobins. J. Biol. Chem., 244: 6105 (1969).

13. Feldman, R., and Reider, R. F.: The interaction of hemoglobin $E$ with thalassemia: A study of hemoglobin synthesis in a family of mixed Burmese and Iranian origin. Blood, 42: 783 (1973).

14. Fessas, P., and Loukopoulos, D.: Alpha-chain of human hemoglobin: Occurrence in vivo. Science, 143: 590 (1964)

15. Flatz, G., Pik, C., and Sringam, S.: Hemoglobin E and $\beta$ thalassemia: Their distribution in Thailand. Ann. Hum. Genet., 29: 151 (1965).

16. Frischer, H., and Bowman, J.: Hemoglobin $\mathrm{E}$, an oxidatively unstable mutation J. Lab. Clin. Med., 85: 531 (1975).

17. Huisman, T. H. J., and Wrightstone, R. N.: Studies on the heterogeneity of hemoglobin. XVI. Separation of variants with a Glu $\rightarrow$ Lys substitution by chromatography on carboxymethylcellulose. J. Chromatogr., 92: 391 (1974)

18. International Committee for Standardization in Hematology: Recommended methods for radioisotopic red cell survival studies. Blood, 38: 378 (1971).

19. Lambeth, J. T., Burns-Cox, C. J., and Maclean, R.: Sacroiliac gout associated with hemoglobin $E$ and hypersplenism. Radiology, 95: 413 (1970).

20. Lundh, B., Cavallin-Stahl, E., and Mercke, C.: Heme catabolism, carbon monoxide production and red cell survival in anemia. Acta. Med. Scand., 197: 161 (1975)

21. Maisels, M. J., Pathak, A., Nelson, N. M., Nathan, D. G., and Smith, C. A.: Endogenous production of carbon monoxide in normal and erythroblastotic newborn infants. J. Clin. Invest., 50: 1 (1971).

22. Mollison, P. L.: Blood Transfusion in Clinical Medicine, 3rd Ed. (F. A. Davis, Philadelphia, 1961).

23. Nathan, D. G., and Gunn, R. B.: Thalassemia: The consequences of unbalanced hemoglobin synthesis. Amer. J. Med., 41:815 (1966).

24. Nienhuis, A. W., Canfield, P. H., and Anderson, W. F.: Hemoglobin messenger RNA from human bone marrow. J. Clin. Invest., 52: 1735 (1973).

25. Pearson, H. A.: Life span of the fetal red blood cell. J. Pediat., 70: 166 (1967).

26. Perutz, M. F., and Lehmann, H.: Molecular pathology of human hemoglobin. Nature, 219: 902 (1968)

27. Sturgeon, P., Itano, H. A., and Bergren, W. R.: Clinical manifestation of inherited abnormal hemoglobins. II. Interactions of hemoglobin $E$ and thalassemia trait. Blood, 10: 396 (1955).

28. Vigi, V., Volpato, S., Gaburro, D., Conconi, F., Bargeliesi, A., and Pontremoli, S.: The correlation between red cell survival and excess of $\alpha$-globin synthesis in $\beta$-thalassemia. Brit. J. Haematol., 16: 25 (1969).

29. Wasi, P., Pootrakul, S., and Na-Nakorn, S.: Hereditary persistence of foetal haemoglobin in a Thai family: The first instance in the Mongol race and in association with haemoglobin E. Brit. J. Haematol., 14: 501 (1968).

30. Wasi, P., Na-Nakorn, S., Pootrakul, S., Sookanek, S., Disthasongchan, P. Pornpatkul, M., and Panich, V.: Alpha- and beta-thalassemia in Thailand. Ann. NY Acad. Sci., 165: 60 (1969).

31. Wasi, P., and Na-Nakorn, S.: Unpublished data (personal communication), August 6, 1974.

32. Weatherall, D. J., Clegg, J. B., Na-Nakorn, S., and Wasi, P.: The pattern of disordered haemoglobin synthesis in homozygous and heterozygous $\beta$-thalassemia. Brit. J. Haematol., 16: 251 (1969).

33. White, P., Coburn, R. F., Williams, W. J., Goldwein, M. I., Rother, M. L., and Shafer, B. C.: Carbon monoxide production associated with ineffective erythropoiesis. J. Clin. Invest., 26: 1986 (1967).

34. Performed through the courtesy of Professor Titus J. J. Huisman

35. Performed through the courtesy of Dr. Arthur W. Nienhuis.

36. The authors are indebted to Mr. James Rogers and Dr. Douglas Tang for excellent technical assistance during this study, to Dr. Paul R. McCurdy for his helpful suggestions and assistance with electrophoresis, and to Dr. Marc Conrad for his suggestions and careful review of this manuscript.

37. The opinions expressed herein are those of the authors and do not necessarily represent the views of the Department of Army.

38. Requests for reprints should be addressed to: Col. Frederick B. Ruymann, M.D., Box 538, Walter Reed Army Medical Center, Washington, DC 20012 (USA).

39. Received for publication October $18,1977$.

40. Accepted for publication January $27,1978$. 